\title{
エリスロマイシン療法施行症例における 副鼻腔粘膜の病理組織学的検討
}

\author{
帝京大学医学部耳鼻咽喉科学教室（主任：鈴木淳一教授)

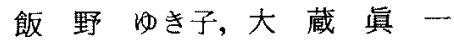 \\ 帝京大学医学部第一病理学教室 \\ 志 賀 淳 治 \\ 国立国際医療センター耳翼咽侯科 \\ 鳥山稔 \\ 国立国際医療センター呼吸器内科 \\ 工 藤 宏一郎
}

\section{HISTOPATHOLOGICAL STUDIES ON PARANASAL MUCOSA FROM PATIENTS TREATED WITH ERYTHROMYCIN}

\author{
YUKIKO IINO, M.D. and SHIN-ICHI OKURA, M.D. \\ Department of Otolaryngology, Teikyo University School of Medicine, Tokyo \\ JUNJI SHIGA, M.D. \\ Department of Pathology, Teikyo University School of Medicine, Tokyo \\ MINORU TORIYAMA, M.D. \\ Department of Otolaryngology, International Medical Center of Japan, Tokyo \\ KOICHIRO KUDO, M.D.
}

Division of Respiratory Diseases, International Medical Center of Japan, Tokyo

Low-dose and long-term administration of erythromycin (EM therapy) has been reported to be very effective for patients with intractable chronic sinusitis including sinobronchial syndrome. However, we sometimes encounter patients whose sinusitis is extremely resistant to EM therapy. Therefore, the present study was carried out to determine the correlation between the clinical efficacy of EM therapy and the histopathological features of the ethmoidal mucosa and nasal polyps of patients treated with erythromycin. Patients with significant lymphocytic infiltration in the submucosal area responded well to EM therapy. Furthermore, patients with neutrophilic infiltration within and beneath the ciliary epithelium tended to show improvement with this therapy. 
On the other hand, EM therapy was minimally effective in patients whose subepithelial layer showed marked eosinophilic infiltration. In patients showing excellent and good clinical results, his tological changes in the paranasal mucosa after therapy were as follows : a decrease in the number of inflammatory cells, reduced interstitial edema, increased fibrosis and normalization of the secretory glands. From these results, we conclude that erythromycin may suppress chronic inflammation except for an allergic reaction characterized by marked eosinophilic infiltration.

Key words : エリスロマイシン, 節骨洞粘膜, 鼻茸, 浸潤細胞

A $97-1070-33135$

はじめに

エリスロマイシン少量長期投与療法 (EM 療法) は, 副鼻腔気管支症候群のみならず下気道症状を伴わない 難治性慢性副鼻腔炎症例に対しても, 従来の保疗療法 に比較して極めて高い有効率が報告されている(12)33. 近年ではこの EM 療法の有效性は，ほほ確立された感 がある，しかし慢性副鼻腔炎症例すべてにおいて有効 ではなく,EM 療法に抵抗する症例もある。そこで今回 われわれは，この $\mathrm{EM}$ 療法の適応を知る意味で, $\mathrm{EM}$ 療法を施行した症例の手術時に摘出した鼻茸または節 骨洞粘膜を病理組織学的に調べそれぞれに扔ける EM 療法の有効性を比較検討した.その結果, EM 療法 の有効性と副鼻曌炎における粘膜病理組織像との間 に，関連が見られたため報告する。

\section{対象ならびに方法}

対象は, EM（またはニューマクロライド）療法（エ リスロマイシン $600 \mathrm{mg} /$ 日, 分 3 ，またはロキシスロマ イシン $150 \mathrm{mg} /$ 日, 朝 1 回投与)を 3 力月以上行い加つ $\mathrm{EM}$ 療法前後に組織学的検索が施行された症例21例 (男15例，女 6 例. 生検または手術時年路 18 歳 79歳) である。エリスロマイシンを投与した症例は15例，口 キシスロマイシンを投与した症例は 6 例であった。こ のうち副鼻腔気管支症候群は13例で，合併している下 気道疾患は, 瀮漫性沉細気管支炎 4 例, 気管支拡張症 2 例, 慢性気管支炎 2 例, 気管支喘息 5 例であった。 下気道症状を伴わない難治性慢性副鼻腔炎症例は 8 例 であった。これらのなかには明確な鼻アレルギー症状 を伴うものはなかったが, 鼻咠を有しかつ鼻X線にて 上顎洞のポリープ様陰影から，アレルギー性副鼻腔炎 が疑われた症例が 1 例存在した。 また過去に鼻副鼻腔 手術の既往があるものは8例で, 内訳は全副鼻腔根本 手術施行例 5 例, 鼻苹摘出術施行例 3 例であった。 た， EM 療法直前に組織採取のため手術あるいは生検
を行った症例は 5 例で,内訳は鼻内篩骨洞開放衙 3 例, 鼻茸摘出のみ 2 例であった.これらは術後 $1-2$ 週間, 術後感染予防のため常用量のマクロライド以外の抗生 物質を投与した後, EM 療法を開始した。

今回の対象となった21症例の, $\mathrm{EM}$ 療法施行時期と, 手術や生検に上る組織摘出時期は以下のとおうであ る。過去あるい梳 $\mathrm{EM}$ 療法直前に組織学的検索が行わ れ，その後 $\mathrm{EM}$ 療法を施行し，再び組織学的検索を行 つた症例 (EM 療法前後に検索した症例) は 6 例，組織 学的検索後に EM 療法を行った症例（EM 療法前症 例）怯 2 例，残りの13例は $\mathrm{EM}$ 療法を施行してから手 術や生検を行った症例 (EM 療法後症例)である．結局 前後で検索しえた症例をあわせる，8症例から $\mathrm{EM}$ 療法施行前の組織が採取でき，また19症例から EM 療 法後の組織が得られたことになる。ただし，この19例 全例とも $\mathrm{EM}$ 投与は，病理組織学検索のための組織摘 出直前まで連続して行われていた。 その EM 療法開始 から病理学的検索までの期間は, EM 療法前にのみ病 理学的検索を行った 2 例を除く上， 3 力月から 36 力月 で平均11.7土10.3力月であった。

各症例に抢ける $\mathrm{EM}$ 療法の有効性は, 病理組織学的 㭘索を行った時点で判定した。ただし 2 例の EM 療法 前症例は，投与後 6 力月の時点にて効果を判定した. 対象症例の効果判定時期を表 1 に示す．EM療法の臨

表 $1 \quad \mathrm{EM}$ 療法の有効性判定時期

\begin{tabular}{cc}
\hline $\begin{array}{c}\text { エリスロマイシン } \\
\text { 投与開始からの期間 }\end{array}$ & $\begin{array}{c}\text { 症例数 } \\
\left(\mathrm{RXM}^{*} \text { 投与症例数 }\right)\end{array}$ \\
\hline $3 \sim 6$ 力月 & $9(5)$ \\
$7 \sim 12$ 力 & $7(1)$ \\
$13 \sim 24$ 力月 & 2 \\
24 力月以上 & 3 \\
\hline 計 & $21(6)$ \\
\hline
\end{tabular}

*RXM：ロキシスロマイシン 
表 $2 \mathrm{EM}$ 療法の効果判定基準

自覚症状

\begin{tabular}{|c|c|c|c|c|c|}
\hline 評点 & $\begin{array}{l}\text { (1 日鼻漏 } \\
\text { (1回数) }\end{array}$ & 後鼻漏 & 䁷閉 & 嗅賞障害 & 䪷星感 \\
\hline 3 & 10回以上 & 常にある & 常につまる & 全く臭わない & 常に痛い \\
\hline 2 & $5 \sim 9$ 回 & よくある & よくつまる & 少し 臭う & 時に中断 \\
\hline 1 & $1 \sim 4$ 回 & 時々ある & 時々つまる & 少し奥いが鈍い & 時々重い \\
\hline 0 & 全くかまない & な L & な L & な ᄂ & な し \\
\hline \multicolumn{6}{|c|}{ 他覚所見 } \\
\hline 評点 & 鼾汁の量 & \multicolumn{2}{|c|}{ 奥汁の性状 } & 捘奥漏の墨 & 奥粘膜の腫脹 \\
\hline 3 & 多 量 & \multicolumn{2}{|c|}{ 膿性 } & 多 量 & \multirow{2}{*}{$\begin{array}{l}\text { 高 度 } \\
\text { 中等度 }\end{array}$} \\
\hline 2 & 中等墨 & \multicolumn{2}{|c|}{ 粘膿性 } & 中等量 & \\
\hline 1 & 少 量 & \multicolumn{2}{|c|}{ 粘性 } & 少 量 & 軽 度 \\
\hline 0 & to L & \multicolumn{2}{|c|}{ 䄻淮性またはなし } & なし & な し \\
\hline
\end{tabular}

表 3 種々の因子と EM 療法の有効性

\begin{tabular}{|c|c|c|c|c|c|c|c|c|c|c|c|c|c|}
\hline \multirow{2}{*}{$\left(x^{\prime} \beth \frac{\text { 定 }}{P}\right)$} & \multirow[b]{2}{*}{ 全症例 } & \multicolumn{2}{|c|}{ 投与期間 } & \multicolumn{3}{|c|}{ 過去の手術 } & \multicolumn{3}{|c|}{$\mathrm{EM}$ 療法直前の手術 } & \multicolumn{2}{|c|}{ 下気道疾患 } & \multicolumn{2}{|c|}{ アレルギー素因 } \\
\hline & & $\begin{array}{c}6 力 5 \\
\text { 以 }\end{array}$ & $\begin{array}{l}7 \text { 虾 } \\
\text { 上 }\end{array}$ & 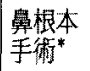 & $\begin{array}{l}\text { 鼻葷 } \\
\text { 摘出 }\end{array}$ & なし & $\begin{array}{l}\text { 鼻内 } \\
\text { 手術 }^{* *}\end{array}$ & $\begin{array}{l}\text { 鼻菆 } \\
\text { 摘出 }\end{array}$ & なし & あり & なし & あり & なし \\
\hline $\begin{array}{c}\text { 著効 } \\
(4,3)\end{array}$ & 6 & 3 & 3 & 2 & 1 & 3 & 1 & 1 & 4 & 3 & 3 & 0 & 6 \\
\hline $\begin{array}{l}\text { 有効 } \\
(2)\end{array}$ & 8 & 3 & 5 & 2 & 1 & 5 & 0 & 0 & 8 & 5 & 3 & 2 & 6 \\
\hline $\begin{array}{c}\text { p户有効 } \\
\text { (1) }\end{array}$ & 4 & 3 & 1 & 0 & 0 & 4 & 2 & 1 & 1 & 2 & 2 & 1 & 3 \\
\hline $\begin{array}{c}\text { 無効 } \\
(0)\end{array}$ & 3 & 0 & 3 & 1 & 1 & 1 & 0 & 0 & 3 & 3 & 0 & 3 & 0 \\
\hline $\begin{array}{c}\text { 有効以上の例数 } \\
\text { 有効率 }(\%)\end{array}$ & $\begin{array}{c}14 / 21 \\
(67)\end{array}$ & $\begin{array}{l}6 / 9 \\
(67)\end{array}$ & $\begin{array}{c}8 / 12 \\
(67)\end{array}$ & $\begin{array}{l}4 / 5 \\
(80)\end{array}$ & $\begin{array}{l}2 / 3 \\
(67)\end{array}$ & $\begin{array}{c}8 / 13 \\
(62)\end{array}$ & $\begin{array}{l}1 / 3 \\
(33)\end{array}$ & $\begin{array}{l}1 / 2 \\
(50)\end{array}$ & $\begin{array}{c}12 / 16 \\
(75)\end{array}$ & $\begin{array}{l}8 / 13 \\
(62)\end{array}$ & $\begin{array}{c}6 / 8 \\
(75)\end{array}$ & $\begin{array}{l}2 / 6 \\
(33)\end{array}$ & $\begin{array}{c}12 / 15 \\
(80)\end{array}$ \\
\hline
\end{tabular}

床効果の判定基準は菊地ら ${ }^{1)}$ の方法に準じて表 2 のご とく評価した。すなわち自覚症状は, 鼻漏, 後鼻漏, 翼閉，嗅覚障䇺，䫒重感の5項目について，また他覚 所見は鼻汁の量, 鼻汁の性状, 後鼻漏, 舅粘膜の腫脹 (鼻龩の大きさ)の4項目について，高度なものから認 められないものまで $3-0$ 点の 4 段階に評点した. EM 療法療法前後に自覚症状, 他賞所見の評点を行い, 投与後の各々における点数の合㖕が，投与前の50\%以 下になったものを改善としてスコア1を与え，50\%以 下でかつ 2 点以下のものを消失としスコア2を与え た。自党症状と他覚所見のスコアの合計したものを臨
床的改善度スコアとし，スコア4，3: 著効, スコア2： 有効, スコア 1: やや有効, スコア0：無効の 4 段階に 評価した。

今回病理学的検索に供した組織は，手術時に前篩骨 洞から摘出した篩骨洞粘膜18標本と鼻茸組織12標本, および外来にて中鼻道加ら摘出した鼻茸組織 9 標本で ある.これらはへマトキシリンーエオジン染色ならびに アルシャンブルー(A1B)-PAS 染色を施した。そして 光学顕微鏡下に400倍の視野て, 線毛上皮直下の炎症性 浸潤細胞（リンパ球，形質細胞，好酸球，好中球，マ クロファージ）の数をカウントし，全浸潤細胞に占め 
る各々の割合を計算した。これを 5 視野で同様に行い, その平均にて各浸潤細胞の占めるパーセンテージとし た。なた，上皮下の浮腫や線維化の程度，さらに粘膜 固有層の分泌細胞の状態を観察した。これらの観点に て, EM 療法の有効例と無効例に打ける組織学的差異 を検徱した。

\section{結果}

1） EM 療法の臨床的有効性

今回組織学的桧討に供した21症例の，EM 療法の臨 床的有効性と種々の因子との関係を表 3 に示す，スコ ア 2 以上の著効, 有効症例は計14例，スコア1以下の やや有効, 無効症例は 7 例で, 前者を有効例とすると 今回の全症例における $\mathrm{EM}$ 療法の有効率は67\%であ つた. 投与期間の長さ, 手術の既往の有無における有 効性の差は見られなかった。 また EM 療法直前の鼻内 手術や鼻茸摘出も，症例は少ないものの $\mathrm{EM}$ 療法の効 果に有意差を与えなかった。また副鼻控気管支症候群 症例13例と，下気道症状を伴わない難治性慢性副鼻腔 炎 8 例における有効率には羑がなかったが，無効例 3 例全例が，副鼻腔気管支症假群の気管支喘息合併症例 であった。よってアレルギーの素因の有無にて有効率 を比較してみると，気管支喘息例 5 例とアレルギー性 副鼻控炎が疑われた 1 症例の計 6 症例中，有効だった のは 2 例で, アレルギー合併なしの症例に比較して, 有効性が低かった。

\section{2) 病理組織学的検討}

線毛上皮直下の炎症性浸潤細胞,すなわちリンパ球, 形質細胞，好酸球，好中球，マクロファージの占める 割合を検討したところ，同一症例では鼻茸と前䇫骨洞 粘膜とも浸潤細胞の種類とその分布はほほ同様であっ たため, 両者が採取されている症例では節骨洞粘膜の 結果で代表させた，EM 療法前後で組織を模索できた 6 症例について, EM 投与前後の 5 視野の上皮下組織
の総浸潤細胞数を表したのが図 1 である，著効十有効 例 3 例中 2 例で，著明な浸潤細胞数の滅少が観察され た.一方有効性の低い例では浸潤細胞の減少は見られ なかった。これら 6 例において, 各浸潤細胞の総浸潤 細胞に占める割合は, 同一症例では EM 療法前後とも ほぼ同様であった。すなわち優位な浸潤練胞は投与前 後でも変化がなかった。

今回の検討に用いた組織を採取する以前，すなわち 過去, あるいは $\mathrm{EM}$ 療法直前に副鼻腔手術や鼻茸摘出 術を受计た場合，それら手術による病理組織上の影響 が当然生じることが予想される。よってこれら手術の 有無による上皮下の浸潤細胞の分布を検討した結果が 表 4 である。その結果, 手術の有無と, 各標本におけ る各浸潤細胞の分布には相関が見られなかった。よっ て浸潤細胞の優位性に関するかぎり，手術の影響はな いと考えられた。また下気道疾患の有無では，副鼻腔 気管支症候群の喘息症例 5 例とも, 浸润細胞は好酸球 が30\%以上を占めたが，その他の下気道疾患並びに下 気道疾患を伴わない副鼻腔単独症例において，有意な

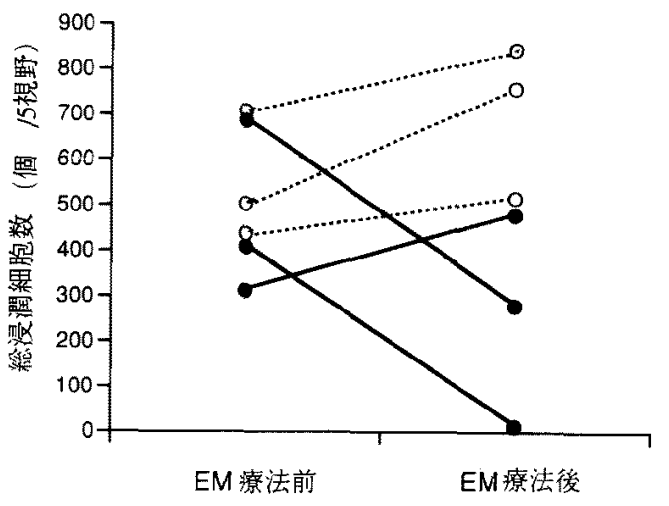

図 $1 \mathrm{EM}$ 療法前後の上皮下漫潤細胞数の変化 実線：著効，有効例 点線：やや有効，無効例

表 4 組織採取以前の手術の有無と上皮下浸潤細胞

\begin{tabular}{|c|c|c|c|c|}
\hline & \multicolumn{4}{|c|}{ 総浸潤細胞に占める割合（\%) } \\
\hline & リンパ球 & 形質細胞 & 好酸球 & 好中球 \\
\hline $\begin{array}{c}\text { 全副鼻腔根本手術 } \\
\text { 鼻内斾骨洞開放術 } \\
(\mathrm{n}=6)\end{array}$ & $47.7 \pm 30.5$ & $16.8 \pm 11.5$ & $24.2 \pm 32.7$ & $6.2 \pm 12.5$ \\
\hline 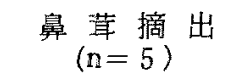 & $52.4 \pm 16.9$ & $17.6 \pm 6.4$ & $25.6 \pm 19.4$ & $1.6 \pm 1.5$ \\
\hline $\begin{array}{c}\text { 手術な } \\
(\mathrm{n}=16)\end{array}$ & $45.7 \pm 14.8$ & $24.3 \pm 11.6$ & $20.3 \pm 21.7$ & $6.3 \pm 7.3$ \\
\hline
\end{tabular}



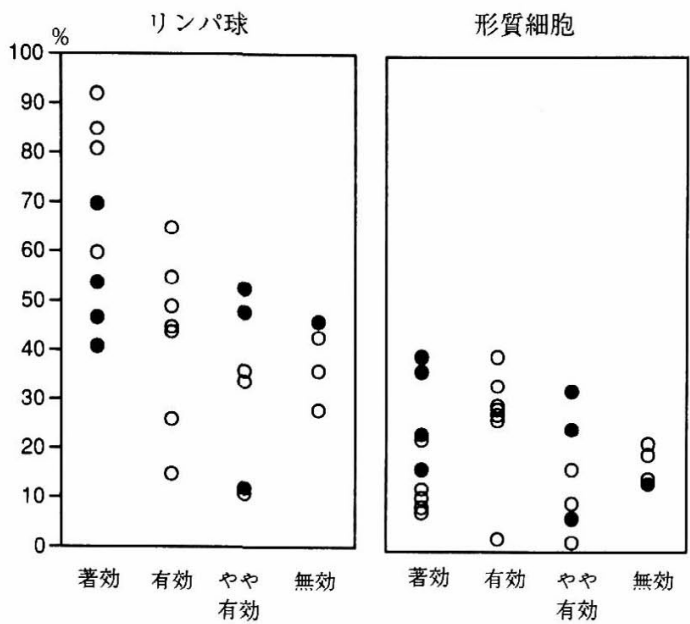

図 $2 \mathrm{EM}$ 療法の有効性とリンパ球, 形質細胞 の上皮下浸潤細胞に占める割合 ：：投与前， $O$ ：投与後）

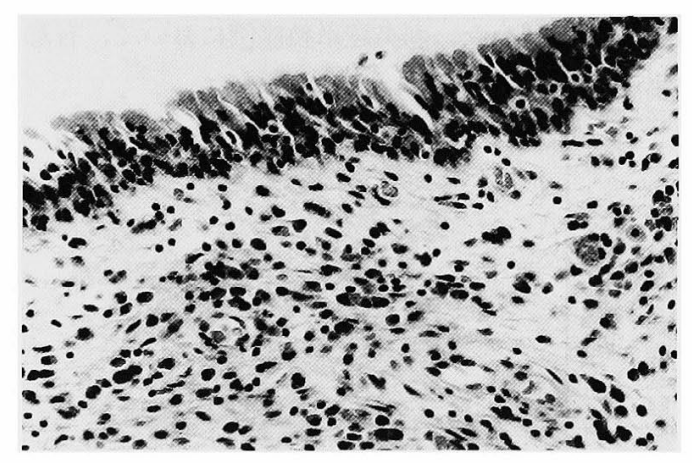

図 3 著効症例（55歳，男）の $\mathrm{EM}$ 療法前の鼻 茸の病理組織像

線毛上皮直下には多数のリンパ球と形質 細胞の浸潤が見られる。

傾向は認められなかった。

つぎに $\mathrm{EM}$ 療法の有効性と浸潤細胞の関係を検討 した. 21症例27標本 (EM 療法前後で組織を採取した 6 症例を含む）における，上皮下のリンパ球と形質細胞 の全浸潤細胞に占める割合を図 2 に示した.リンパ球, 形質細胞とも有効症例ほど全浸潤細胞に占める割合が 多い.これを著効十有効例と，やや有効十無効例の 2 群に分けて統計学的に検定すると, リンパ球は前者に おける平均が $54.8 \pm 19.2 \%$ ，後者は $34.7 \pm 13.5 \%$ で 2 群間に有意差がみられた（ $\mathrm{p}<0.05 ）$ 。また形質細胞は 前者は $24.3 \pm 11.8 \%$, 後者は $16.5 \pm 8.6 \%$ で有効例に形
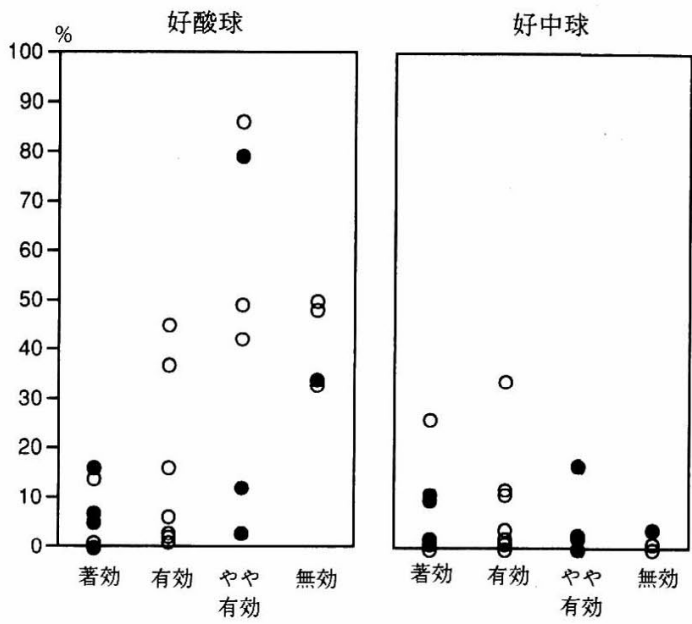

図 $4 \mathrm{EM}$ 療法の有効性と好酸球, 好中球の上 皮下浸潤細胞に占める割合

$(\mathrm{O}$ : 投与前, $\bigcirc$ : 投与後)

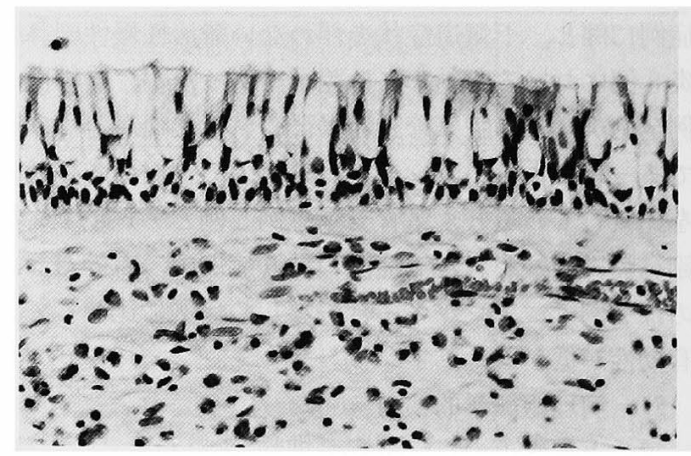

図 5 無効症例（49歳, 男) の $\mathrm{EM}$ 療法後の篩 骨洞粘膜病理組織像

線毛上皮直下には多数の好酸球の浸潤が 見られる。

質細胞の占める割合が高かったが有意差は見られなか った. 図 3 は著効と判定した症例の $\mathrm{EM}$ 療法前の鼻茸 の病理組織像である。上皮下には多数のリンパ球及び 形質細胞の浸潤が見られ, リンパ球と形質細胞の全浸

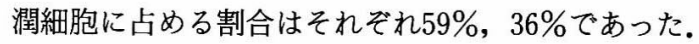

さらに各症例における好酸球と好中球の占める割合 を示したのが図 4 である. 有効性の低い症例では好酸 球の占める割合の高い症例が多いのに比して，著効症 例では好酸球の出現程度が低い症例が多い，著効十有 効例とやや有効十無効例の 2 群に分けて有意差を検定 すると，前者にて好酸球の占める割合の平均は $9.6 \pm$ 


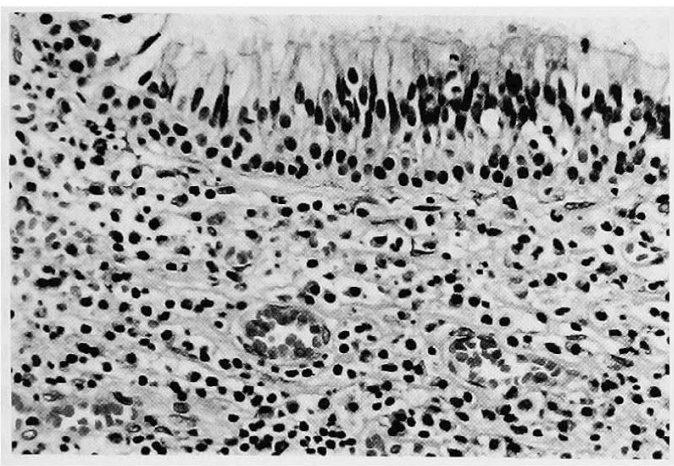

図 6 著効症例 (69歳，女）の $\mathrm{EM}$ 療法後の篩 骨洞粘膜病理組織像

上皮内と上皮直下に好中球の浸潤が見ら れる.

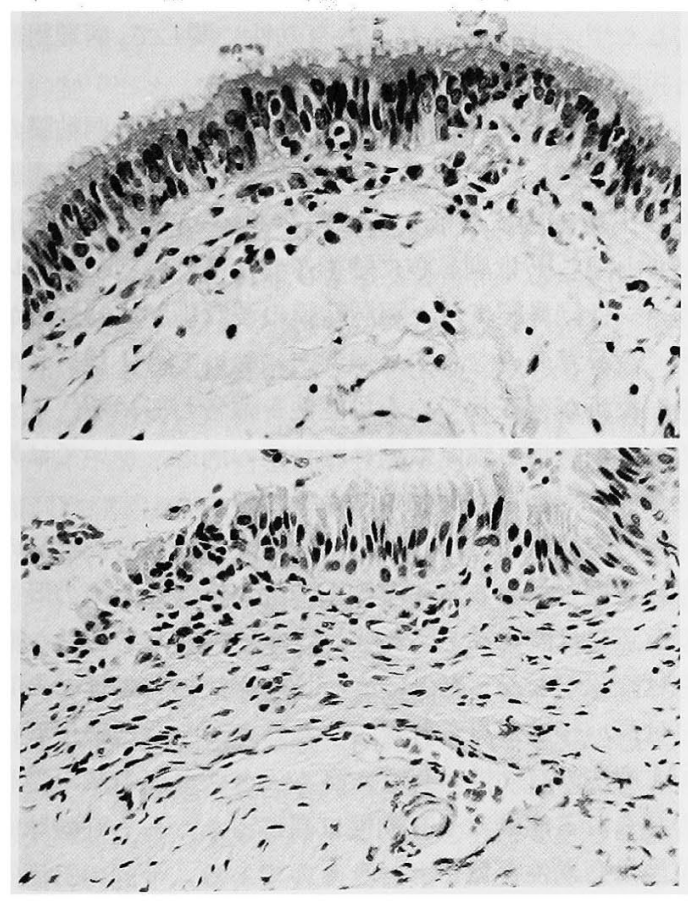

図 7 著効症例 (24歳, 男) の EM 療法前後の 笠骨洞粘膜病理組織像

上：投与前, 下：投与後

投与前には著明な間質の浮腫が見られる が, 投与後には浮腫が消退し代わりに線 維化が見られる。

$12.6 \%$, 後者では $43.6 \pm 24.5 \%$ と有意差が認められた $(\mathrm{p}<0.001)$.また好中球の総浸潤細胞に占める割合 は，ほとんどの症例で非常に低い，中には全く出現を

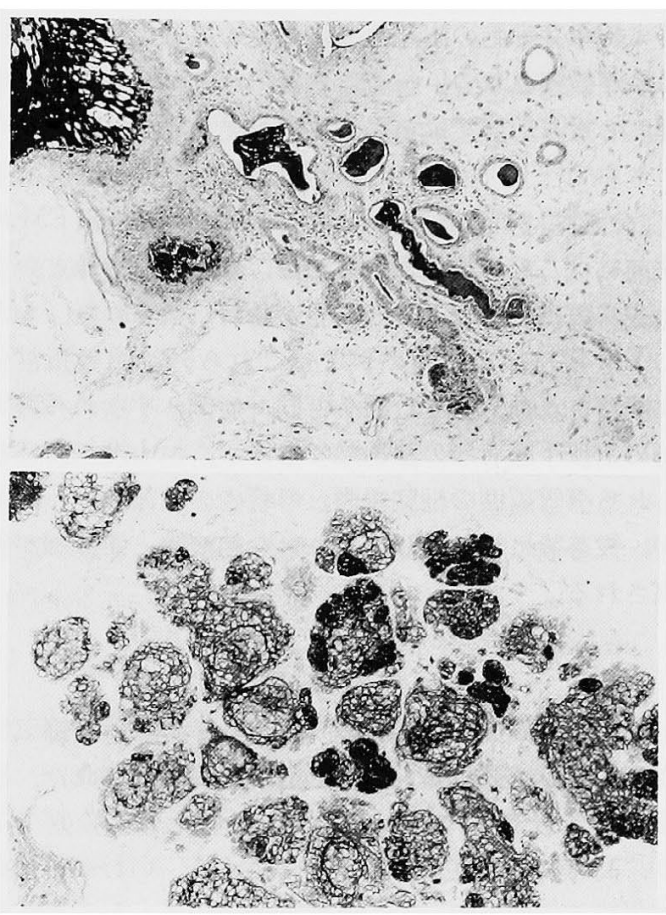

図 8 著効症例 (24歳, 男) の EM 療法前後の 笁骨洞粘膜固有層の腺組織 AlB-PAS (pH 2.6) 染色. 上：投与前, 下：投与後

みない症例もある. 著効十有効例と，やや有効十無効 例の 2 群間では, 好中球の占める割合には有意差は認 められなかった。しかし $10 \%$ 以上好中球が認められた 症例 7 例中の 6 例は有効症例であり, 好中球が多く観 察される症例では $\mathrm{EM}$ 療法が有効な症例が多いとい える. マクロファージはすべての症例にて $3 \%$ 内外見 られた. 図 5 は無効と判定された症例の EM 療法後の 篩骨洞粘膜組織である.上皮下組織には多数の好酸球 の浸潤を見，総浸潤細胞数の $48 \%$ を占めている.図 6 は著効例の篩骨洞粘膜組織である. 上皮直下には，多 数のリンパ球と形質細胞の浸潤が見られるが, 好中球 も線毛上皮内及び上皮直下に出現しているのが見られ る.

上皮下間質組織における浮腫と線維化の程度を, EM 療法前後にて検討すると, 著効や有効症例では EM 療法後に浮腫が軽減し, 代わって線維化が起きて くる症例が多かった. 図 7 は著効例の EM 療法前後の 篩骨洞粘膜組織である. EM 療法前には間質の著明な 浮腫が見られるが, EM 療法後には浮腫も消退し, 代わ 
って線維芽細胞の出現と共に高度の線維化が生じてい るのが観察される。一方無効例で法, 浮腫も線維化の 程度も投与前後でほとんど変化が見られなかった。

さらに上皮下の固有層の腺組織の状態を観察する と, 分泌腺は槳液腺と粘液腺の混合腺であるが, EM 療 法前にはこれら腺組織の破壊像, 導管の拡張像といつ た分泌障害を示唆させる所見が随所に見られた。しか し EM 療法後には有効例ではこれら分泌腺の正常化 が観察された。図 8 は図 7 と同一症例, すなわち著効 例の上皮下固有層の腺組織であるが，EM 投与前にみ られる導管周囲の細胞漫潤, 導管内の粘液のうっ滞像 が, 投与後には消失してきれいな粘液腺, 漿液腺が観 察される。

\section{考按}

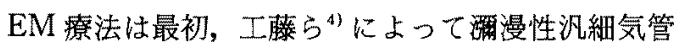
支炎に対して試みられ，その有効性が報告された。洒 漫性沉気管支炎は極めて難治な慢性気道感染症であ り，高頻度に慢性副鼻腔炎を合併する，いわ方る副鼻 腔気管支症候群の一つの病態を形成する。この $\mathrm{EM}$ 療 法は，他の副鼻腔気管支症候群や下気道症状を伴わな い難治性慢性副鼻腔炎に対しても試みられている。そ の結果，下気道疾患の有無にかかわらず，難治性慢性 副奥腔炎に対して，自覚症状，他覚所見の臨床的改善 率は60-80\% と非常に高い有効性が報告されてい $3^{(13) 51}$. 森山 $ら^{6)}$ も内視鏡鼻腔整復術を行った症例に 对し, 術後に EM 療法を施行した症例は非施行例に比 べ，自覚症状，他覚所見とも改善が著明だったとして いる．また近年，エリスロマイシンの誘導体である14 員環のマクロライド（ニューマクロライド）が, 同様 の効果を難治性の呼吸器疾患及び副鼻腔炎に示すこと が報告されている ${ }^{78899}$. 今回の我々の対象症例21例に おける副鼻腔炎に対する、ニューマクロライドを含す $\mathrm{EM}$ 療法の有効率は67\%であった。これは従来の報告 による改善率よりやや低い上うであるが，我々の症例 ではほとんどのものが鼻茸を伴って扔り，また 3 分の 1 の症例で手術既往があり，過去の手術によっても改 善がもたらされなかった難治症例がほとんどであった ためと思われる．それにもかかわらず，半数以上で満 足すべき臨床効果を得ることができたことは，EM 療 法の有効性を物語っている. しかし無効症例が存在す ることも事実である。

慢性副鼻空炎には種々の病態がある.すなわち下気 道疾患の伴うもの，副鼻腔手術を受けたもの，鼻茸を
伴うもの，灰病期間の羑，アレルギー素因の強いもの 等々である。菊地ら ${ }^{5}$ は種々の臨床像と EM 療法の有 効性を比較検討した。その結果, 副鼻腔気管支症侯群 の有無，副鼻腔手術の有無による有効性の差は見られ ないとしており，今回のわれわれの結果とも一致して いる．また小児例の有効性は成人例に比しやや劣ると している，その他の因子による有効性の比較の報告は ない．われわれの検副ではンルギー性の要因が強い ものの有効性は低かった，とくに副鼻腔気管支症候群 の喘息症例 5 例中 3 例は全く $\mathrm{EM}$ 療法の効果が見ら れなかった。われわれは以前，滲出性中耳炎を伴う副 鼻腔気管支症候群症例に対L EM 療法を施行L, $80 \%$ 以上の症例にて副鼻腔炎，下気道症状の改善とともに 中耳貯留夜の消失をみたか，気管支喘息症例の有効性 は低く，渗出性中耳炎も不変の症例があったことを報 告した ${ }^{10)}$.今回はさらにこの有効性に関して, 病理組織 と相関がないかどうか検討を試みた。

われわれは同一症例において，鼻茸と筫骨洞粘膜の 両方を比較したところ，その組織像，とくに各浸潤細 胞の出現頻度には活とんど差がないという結果を得

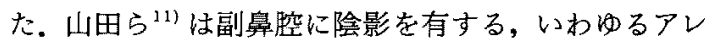
ルギー性副鼻腔炎の上顮洞粘膜の浸潤細胞は好酸球が 多く，鼻茸のみならず上顎洞内においてもI 型アレル ギー反応が存在している可能性を報告している，よっ て鼻茸の病理組織像は副鼻腔粘膜の病態，ひいては鼻 腔全体の病態をも反映しているといえる。

今回の検討にて，われわれは上皮下の各浸潤細胞の 割合を調べたところ，浸潤細胞の優位性は手術の既往 の有無には関係なく，また EM 療法前後でも優位な細 胞は変化がなかった. しかし EM 療法の有効性との間 には高い相関が見られた。すなわちりンパ球優位型は $\mathrm{EM}$ 療法の有效性が有意に高く，さらに好中球の漫潤 の見られる症例でも有效性は高かった。一方好酸球優 位型は有効性が低いというものである.今回の21症例 では，好酸球が上皮下浸潤細胞のなかで占める割合が， もっとも高かったのは 6 例であり，また $30 \%$ 以上占 め大症例は 8 例であった。これら 8 症例のうち，5例 は喘息症例，1例はいわゆるアレルギー性副鼻腔炎が 疑われた症例であるが，2例は全くアレルギー疾患の 既往が認められないものであった，好酸球浸潤をみる 鼻茸を有する患者の約 7 割はアトピーではないとの報 告 ${ }^{12)}$ があること加ら，明確な喘息などのアレルギ一疾 患が同定できなくともその副鼻腔病態が好酸球優位で ある可能性は大きい.よって EM 療法の有効性も臨床 
像のみからでは推定できない。

EM 療法の有效性は従来の抗生物雷としての抗菌作 用にあるのではなく，抗炎症作用ないしは兔疫調節作 用にあるとされている4.すなわち，瀮漫性汎細気管支 炎や副鼻腔気管支症候群の患者では，寒冷凝集反応が 高值を示すものが多く，ある種の免疫異常が存在する 可能性がある，しかし EM 療法にてこの寒冷凝集価が 正常值にもどることが報告されている13. さらにエリ スロマイシンに感受性のない緑膿菌などの病原菌が消 失する場合もある.今回の症例でも2 例にて, 投与後 に中鼻道から緑膿菌の消失をみた。エリスロマイシン はとくに免疫担当細胞に高濃度に取り込まれることか ら，これらの細胞に対する効果が報告されている。す なわち，好中球や単球の遊走活性や活性酸素洨生入口 影響 $^{141515\rangle}$, リンパ球 Natural Killer 活性の増強 ${ }^{16)}$, 単 球のインターロイキン-1 (IL-1) や腫湟壊死因子産生

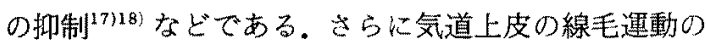

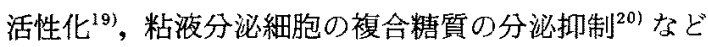
も報告されている，われわれの症例では有効例で腺分 泌細胞の正常化が見られている。

慢性副鼻腔炎においては種々のタイプの細胞が粘膜 下免疫反応や炎症反応にかかわっている，リンパ球や 白血球，さらには好酸球などの浸潤細胞の遊走はさま ざまな因子にて制御されている。これらには接着分子 やサイトカインが含まれる、事実，慢性副畀腔炎の上 䫓洞粘膜組織には ICAM-1 ELAM-1 という接着 分子や，IL-1 $\beta$ が発現していることが報告されてい る ${ }^{21}$ まな炎症の治愈に重要な働きを演ずる線維芽細 胞もサイトカインに制御されている。前述したように エリスロマイシンが種々の炎症細胞の機能に影響を及 ぼすがきり，副鼻空粘膜に浸潤している細胞の種類に よってその効果が賢なるのは当然考えられることであ る.今後接着分子やサイトカインの発現をさらに追及 することによって，それらの発現と副鼻腔炎の病態， さらには EM療法の作用部位が明らかになると思わ 机了。

今回の研究から，上皮下浸潤細胞の種類によって， ある程度 $\mathrm{EM}$ 療法の効果が予測できると考えられる ため，投与を計画する際はできればあらかじめ鼻革組 織などを生榆し，その病理組織像を検討してから投与 することが望ましいと考えられた。ささらに好酸球優位 の症例に対しては，ステロイドの点鼻や抗アレルギー 剂の併用を行うことにより EM 漝法の有效性が增す 可能性もあり，今後検討する必要があると思われた。
まとぬ

1）EM 療法を施行した難治性慢性副鼻腔炎症例21 例の，鼻茸及び前管骨洞粘膜を病理組織学的に調べ， その有効性と比較検討した。

2） $\mathrm{EM}$ 療法の有効な症例では線毛上皮直下の浸潤 細胞はリンパ球が㑩位であった。

3）好酸球優位の症例では，EM 療法の有効性が有 意に低加った。

4）上皮下や上皮内に好中球が多く出現している症 例では，EM療法が有効である場合が多かった。

5） $\mathrm{EM}$ 療法有効例で证投与後に炎症細胞の減少， 浮腫の隇少, 線維化の増強, 分泌腺組織の正常化が見 和な。

\section{参考文献}

1）菊地茂，洲崎春海，青木彰彦，伊藤修，野村恭也：

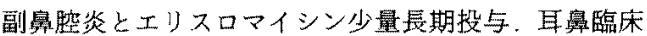
$84: 41-47,1991$.

2）高北晋一，北村溥之，大八木章博，西川益子，田朔

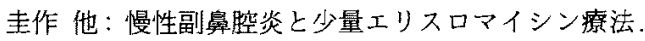
耳鼻臨床 84：489 498，1911.

3）小野幹夫，若盛和雄：難治性慢性副鼻空炎に対するエ リスロマイシンの長期投与の試み:耳展 34: 639$645,1991$.

4) 工藤翔三，木村 仁，植竹健司，两山雅清，久田哲哉 他：びまん性汎気管支炎にたいするマクロライド系抗 生剂の少量長期投与の臨床効果。日胸疾会誌 22 (増) : 254,1984 .

5）荻地茂，山岨達也，洲崎春海，青木彰童，原誠 他：副鼻腔炎とエりスロマイシン少量長期投与一第 2 報一。耳鼻臨床８5：1245-1252，1992。

6）森山寛，柳清，鴻信義，金田健作、深見雅也 他：内視鏡下鈿空整復術の術後成績一エリスロマイシ ン（術後少量長期）投与例と非投与例の比較一，耳展 35: 351-356, 1992.

7) 羽柴基之，宮本直载，木村利男，馬場駿吉，小林武弘：

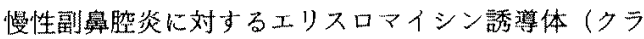
リスロマイシン) の効果，日鼻誌 32: 269-280, 1993.

8）平賀 智: 慢性副鼻踥炎へのクラリスロマイシンの効 果。年鼻臨床 86:609 613，1993.

9）藤森敏也，松周 出，中村 隆，杉丸忠彦，池上 聡： 慢性副鼻腔炎に対するルリッドの效果。耳鼻臨床 $86: 761-766,1993$.

10) Iino $Y$, Sugita $K$, Toriyama $M$ et al : Erythromycin therapy for otitis media with effusion in sinobron 
chial syndrome. Arch Otolaryngol Head Neck Surg $119: 648-651,1993$.

11）山田弘之：鼻アレルギー患者の上顎洞粘膜に抢ける浸 潤細胞の定量的検討。日耳鼻 $93: 1999-2008 ， 1990$.

12) Ogawa $\mathrm{H}$ : Atopic aspect of eosinophilic nasal polyposis and a possible mechanism of eosinophil accumulation. Acta Otolaryngol (Stockh) Suppl $430: 12-17,1986$

13）工藤翔二：細気管支疾患の臨床。びまん性沉細気管支 炎. 肺と心 37：184-194，1990.

14) Anderson R: Erythromycin and roxithromycin potentiate human neutrophil locomotion in vitro by inhibition of leukoattractant- activated superoxide generation and autooxidation. J Infect Dis 159: 966-973, 1989.

15) Roche $Y$, Gougerot-Pocidalo MA, Fay $M$ et al Macrolides and immunity : effects of erythromycin and spiramycin on human mononuclear cell proliferation. J Antimicrob Chemother 17 : 195-203, 1986.

16）三笠桂一，澤木正好，古西 満，江川信一，米田尚弘 他：慢性下気道感染症患者におけるエリスロマイシン 治療の Natural Killer 細胞活性に与元る影響. 感染 症誌 63:811-815, 1989 .

17) Takeshita K, Yamagishi I, Harada $M$ et al: Immunological and anti-inflammatory effects of clarithromycin; inhibition of interleukin 1 production of murine peritoneal macrophages. Drug Expt1 Clin Res 15: 527-533, 1989.

18) Inno $\mathrm{Y}$, Toriyama $\mathrm{M}$, Kudo $\mathrm{K}$ et al : Erythromycin inhibition of lipopolysaccharide-stimulated tumor necrosis factor alpha production by human monocytes in vitro. Ann Otol Rhinol Laryngol Suppl $157: 16-20,1992$.

19）玉置淳，武山廉，千代谷眾、坂井典孝，山内 富美子 他：気道粘膜上皮の線毛運動に対するロキシ スロマイシンの効果とその作用機序に関する検討．呼 吸と循環 39：481-485，1991。

20) Goswami SK, Kivity S, Marom $Z$ : Erythromycin inhibits respiratory glycoconjugate secretion from human airways in vitro. Am Rev Respira Dis 141: $72-78,1990$

21）徳重栄一郎, 伊東一則, 松崎 勉, 福田勝則, 大山 勝: 慢性副鼻腔炎患者の上顎洞粘膜にお打る IL- $1 \beta$ 招上 び血管内皮細胞上接着分子の発現。炎症 13:369375, 1993.

本論文の要旨は第94回日本耳鼻咽㘈科学会総会にてワ演 した.

（1993年 9 月 10日受稿 1994年 2 月 3 日受理）

別刷請求先 $=173$ 東京都板橋区加賀2-11-1

帝京大学医学部耳毁咽喉科学教空 飯野他き子 